\title{
KOMBINASI TEKNOLOGI ECODRAINAGE DAN ALAT PENYEDOT SEDIMEN (DOMEN) SEBAGAI SOLUSI BEBAS BANJIR
}

\author{
Anita Rahmawati*, Nurlailatul Khusnah, Qurasun Shieldhan Nabil H. \\ Fakultas Teknik, Universitas Islam Malang \\ *korespondensi email: anita.rahmawati@unisma.ac.id
}

\begin{abstract}
ABSTRAK
Permasalahan saluran di perkotaan adalah berubahnya status saluran dari saluran irigasi ke saluran drainase. Keberadaannnya cenderung menjadi tempat sampah, sehingga apabila hujan deras akan menyebabkan tersumbat dan banjir. Di lingkungan Kelurahan Petamanan dilakukan upaya - upaya untuk menormalisasi saluran supaya berfungsi kembali, seperti normalisasi saluran, pengecatan saluran, pengerukan sedimen, pemasangan banner larangan membuang sampah dan pemasangan vertical garden, serta konsep alat penyedot sedimen (domen). Upaya tersebut dilakukan oleh mahasiswa Unisma Malang yang dibimbing oleh Dosen Pembimbing Lapangan (DPL). Program KSM Tematik ini dilakukan bersama warga setempat, diharapkan kegiatan tersebut mampu membuat lingkungan bersih, sehat, nyaman, bebas sampah dan bebas banjir dengan inovasi yang telah dibuat.
\end{abstract}

Kata Kunci: ecodrainage; normalisasi; bebas banjir

\section{PENDAHULUAN}

Indonesia dikenal sebagai negara terpadat nomor 4 di dunia, sehingga sanitasi yang dialirkan dari saluran drainase juga harus diperhatikan (Arieza, 2018; Oktiawan \& Amalia, 2012). Saluran di perkotaan yang cenderung kotor, dangkal, tidak terawat dan rusak, apalagi ditambah perilaku masyarakat yang kurang memahami betapa pentingnya untuk lingkungan sekitar seperti menjadikan saluran sebagai tempat pembuangan limbah rumah tangga baik padat maupun cair. Sehingga apabila musim penghujan tiba akan cenderung menyumbat dan menyebabkan banjir (Fairizi, 2015; Yunik'ati et al., 2019).

Dalam rangka menjamin kebersihan sanitasi dan bebas banjir di masa pandemi Covid-19 di Indonesia, Pemerintah telah menyiapkan berbagai strategi seperti melakukan program pembangunan berkelanjutan untuk mencapai universal akses dalam sektor air minum, air bersih, dan sanitasi seperti program WASH (Water, Sanitation, and Hygiene) (Rudyansyah, 2019; Sinatrya \& Muniroh, 2019). Dimana Tindakan preventif tersebut seperti sarana sanitasi khusus pasien terduga terkena Covid-19 harus menyediakan kamar mandi dan jamban terpisah dari tenaga medis dan para pasien yang tidak terjangkit Covid-19, atau apabila tidak memungkinkan, kamar mandi dan jamban tersebut harus diberi disinfektan minimal sehari sekali.

Perguruan Tinggi saat ini menjadi sangat penting dalam mencapai program pembangunan yang berkelanjutan di Indonesia sebab dapat memberikan pandangan, pemikiran, dan masukan terhadap strategi kebijakan yang akan diambil oleh Pemerintah serta menciptakan inovasi yang mampu menjamin pembangunan yang berkelanjutan di era new normal pandemi Covid 19, seperti halnya Universitas Islam Malang yang melaksanakan 
KKN Tematik Edisi Covid 19. Dalam menjalankan kegiatan sosialisasi sanitasi di saluran drainase dengan konsep ramah lingkungan, KKN Tematik Edisi Covid 19 Universitas Islam Malang Kelompok 80 selalu memperhatikan kondisi masyarakat terlebih dahulu, selalu memperhatikan protokol kesehatan, cuci tangan maupun jaga jarak agar memutus penyebaran mikroba kepada orang lain disekitarnya. Kesehatan menjadi salah satu masalah penting dalam dunia sanitasi. Dengan demikian maksud adanya pembersihan saluran drainase ini tak lain karena bentuk kepedulian kepada masyarakat dengan melakukan sosialisasi tentang pentingnya menerapkan vertical drain, pembersihan saluran, dan pengecatan saluran sebagai konsep ecodrainage, serta di era sekarang demi keberlanjutan dalam pembangunan.

Sebagai langkah awal untuk melaksanakan kegiatan tersebut, dilakukan diskusi dan sosialisasi dengan warga sekitar. Bagaimana merubah saluran yang berada di lingkungan RT.03 RW.01 menjadi bersih, sehat, memliliki daya tampung yang lebih besar, terlihat indah serta memberikan solusi supaya masyarakat tidak membuang sampah sembarangan, dan yang ramah lingkungan. Akhirnya disepakati dilakukan bersama dengan masyarakat sekitar untuk melakukan pengerukan sedimen, perbaikan saluran untuk menambal pasangan yang rusak, dilakukan pengecatan saluran dan memasang banner serta vertical garden.

Sedimen yang ada cukup tebal, tetapi karena keterbatasan tenaga yang dilakukan pengerukan hanya sedalam $\pm 20 \mathrm{~cm}$ dan sepanjang $\pm 120 \mathrm{~m}$. Dalam melakukan pengerukan kendalanya adalah sulitnya mengeruk sedimen yang berada di bawah jembatan, apabila dilakukan secara manual akan sulit. Diperlukan alat penyedot sedimen untuk menjangkau lokasi yang sulit. Setelah dilakukan pengerukan maka kapasitas tampungan menjadi lebih banyak, sedimen terangkat, sehingga apabila musim kemarau saluran tidak berbau, saluran lebih sehat, dan ramah lingkungan.

\section{METODE}

KKN Tematik dengan Tema Kandidat Sarjana Mengabdi (KSM) Berbasis Keilmuan dan Domisili di Universitas Islam Malang Kelompok 80 mengambil judul "Kombinasi Teknologi Ecodrainage dan Alat Penyedot Sedimen (DoMen) Sebagai Solusi Bebas Banjir" ini menggunakan beberapa tahapan, diantaranya (1) Pada tahapan identifikasi permasalahan di lapangan menggunakan metode wawancara. Wawancara digunakan sebagai teknik pengumpulan data untuk menemukan permasalahan dan mengetahui hal-hal dari responden yang lebih mendalam. (2) Proses identifikasi masalah dapat dilakukan dengan mendeteksi permasalahan sosial yang diamati kemudian mengambil langkah untuk mengetahui lebih lanjut, bisa dengan melakukan survey awal, dan (3) Proses sosialisasi dalam merencanakan dan penerapan teknologi yang ramah lingkungan.

Lokasi KKN Tematik Kandidat Sarjana Mengabdi (KSM) Berbasis Keilmuan dan Domisili di Universitas Islam Malang Kelompok 80, berada di Kelurahan Pertamanan, Kecamatan Panggungrejo, Kota Pasuruan, Provinsi Jawa Timur. Alasan memilih tempat tersebut yaitu selain untuk mengembangkan Kelurahan Pertamanan di bidang pembangunan dan sanitasi juga ada bagian yang sangat berpotensi yang dapat disentuh dengan teknologi yang ramah lingkungan agar masyarakat sekitar terbebas dari banjir. 


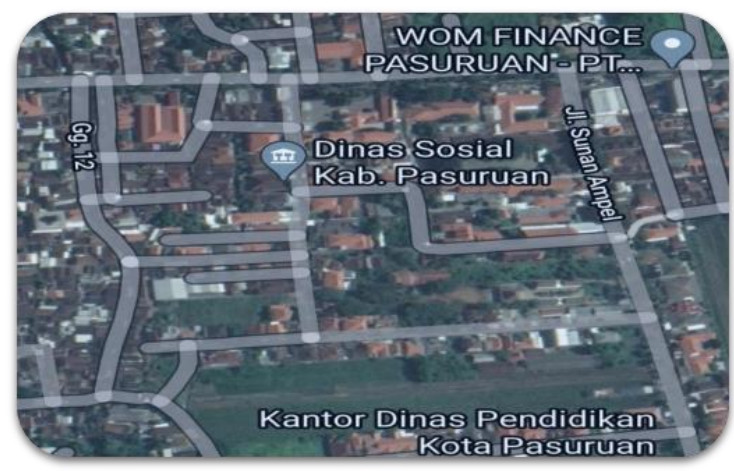

Gambar 1. Lokasi KKN Tematik Kelompok 80

Adapun waktu pelaksanaan KKN Tematik ini dilakukan pada tanggal 08 Februari 2021 s/d 06 Maret 2021. Responden adalah semua orang baik secara individu maupun kolektif yang akan dimintai keterangan yang diperlukan oleh pencari data. Kemampuan responden sedikit banyak mempengaruhi jawaban atau informasi yang diberikan, terutama kalau pertanyaan menyangkut nama baik daerah atau pernyataan yang bersifat sensitive. Untuk mendapatkan informasi yang baik tentunya kita harus mengetahui waktu luang yang dimiliki masyarakat sekitar guna memperoleh informasi yang lebih baik.

\section{HASIL DAN PEMBAHASAN}

Kegiatan sosialisasi khususnya program studi teknik sipil yang dilaksanakan oleh Kelompok 80 KKN Tematik Kandidat Sarjana Mengabdi (KSM) Berbasis Keilmuan dan Domisili di Universitas Islam Malang, di Kelurahan Pertamanan, Kecamatan Panggungrejo, Kota Pasuruan, Provinsi Jawa Timur, dilakukan melalui beberapa tahapan yaitu:

1. Survey lokasi dilakukan untuk mencari informasi tersendiri dari masyarakat sekitar mengenai kondisi lingkungannya dan nantinya mampu melihat potensi dan hambatan dari Kelurahan Pertamanan tersebut, kami perhatikan hampir 80\% masyarakat kurang memperhatikan kebersihan lingkungan dan kurangnya kesadaran akan keberadaan saluran tersebut. Dari hasil survey yang dilakukan di Kelurahan Pertamanan terdapat beberapa fakta yang menunjukkan hasil sebagai berikut: (1) Kurangnya pemahaman tentang drainase yang ramah lingkungan; (2) Masyarakat sering mengabaikan masalah kebersihan lingkungan; dan (3) Saluran masih dianggap sebagai tempat pembuangan limbah padat.

2. Langkah berikutnya untuk melaksanakan kegiatan tersebut, dilakukan diskusi dengan warga sekitar. Bagaimana merubah saluran yang berada di lingkungan RT.03 RW.01 menjadi bersih, sehat, memliliki daya tampung yang lebih besar, terlihat indah serta memberikan solusi supaya masyarakat tidak membuang sampah sembarangan. Akhirnya disepakati dilakukan bersama dengan masyarakat sekitar untuk melakukan pengerukan sedimen, pebaikan saluran untuk menambal pasangan yang rusak, dilakukan pengecatan saluran dan memasang banner serta vertical garden.

3. Melakukan pengerukan sedimen sedalam $\pm 20 \mathrm{~cm}$ dan sepanjang $\pm 120 \mathrm{~m}$. Dalam melakukan pengerukan kendala yang ada adalah sulitnya mengeruk sedimen yang berada di bawah jembatan, apabila dilakukan secara manual akan sulit. Maka untuk itu kami juga melakukan sosialisai alat penyedot sedimen untuk menjangkau lokasi yang sulit. Setelah dilakukan pengerukan maka kapasitas tampungan menjadi lebih banyak, sedimen terangkat, sehingga apabila musim kemarau saluran tidak berbau, saluran lebih sehat.

4. Setelah dilakukan pengerukan dan perbaikan saluran, maka dilakukan pengecatan warna - warni pada saluran. Bertujuan agar saluran menjadi lebih indah, warga lebih 
peduli, warga lebih merasa memiliki saluran tersebut, dan ada sikap malu apabila ada yang membuang sampah di saluran. Pengecatan dilakukan semenarik mungkin agar warga sekitar semakin semangat menjaga kebersihan saluran. Manfaatnya selain saluran menjadi bersih, lebih indah, juga sebagai sarana rekreasi yang murah karena berada di depan rumah. Kendalanya adalah di tenaga dan biaya, sehingga dari swadaya masyarakat yang terbatas, masih ada beberapa titik yang belum sempat di cat.

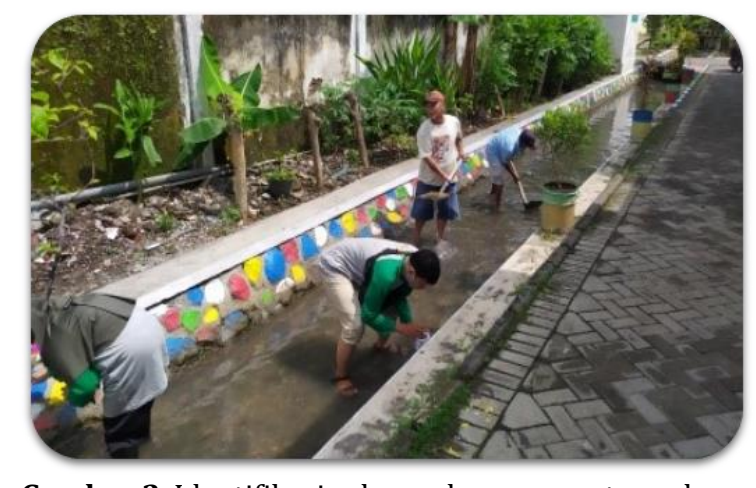

Gambar 2. Identifikasi saluran dan pengecatan saluran

5. Mengedukasi masyarakat dan merubah perilaku masyarakat agar tidak membuang sampah sembarangan agak sulit dilakukan. Sebagai agen perubahan mahasiswa melakukan kegiatan pemasangan poster dilarang membuang sampah dan memasang vertical garden di saluran yang dekat dengan jalan. Sehingga akan menyulitkan warga apabila melempar sampah ke saluran, karena terhalang vertical garden. Kendalanya adalah pada biaya sehingga hanya 1 titik lokasi yang dipasangi vertical garden dan hanya 2 titik lokasi yang dipasangi banner larangan membuang sampah.

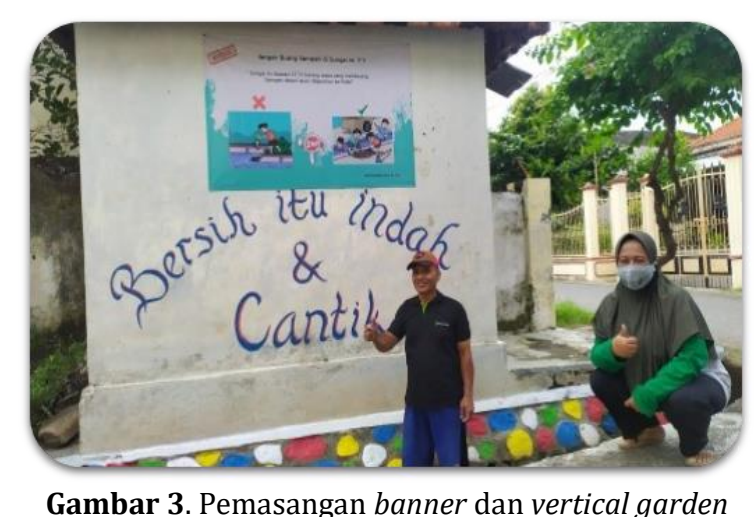

Upaya-upaya yang dilakukan diatas merupakan implementasi dari pelaksanaan Peraturan Dearah Kota Pasuruan Nomor 32 tahun 2011 tentang Pengelolaan Sampah Bab XII LARANGAN Pasal 50 huruf c : "Setiap orang dilarang membuang sampah di sungai, parit, drainase, saluran irigasi, taman kota, tempat terbuka, fasilitas umum dan jalan.

Selama 1 (Satu) bulan kegiatan dilakukan, dapat disimpulkan bahwa apabila ada yang memulai melakukan kegiatan pembersihan dan normalisasi saluran maka warga sekitar akan ikut tergerak untuk mensukseskan. Karena merasakan langsung hasilnya, merasakan manfaat dari saluran yang bersih, saluran yang indah bebas bau. Menumbuhkan rasa memiliki dan kepedulian di wilayah perkotaan memang agak sulit, tetapi itu bukan hal tidak mungkin. Secara sukarela warga ikut melakukan pembersihan saluran, melakukan 
pengerukan saluran, melakukan pengecatan saluran, memasang banner dan memasang vertical garden.

\section{KESIMPULAN}

KKN Tematik dengan Tema Kandidat Sarjana Mengabdi (KSM) Berbasis Keilmuan dan Domisili di Universitas Islam Malang Kelompok 80 mengambil Judul "Kombinasi Teknologi Ecodrainage dan Alat Penyedot Sedimen (DoMen) Sebagai Solusi Bebas Banjir" mendapatkan sambutan positif dari masyarakat sekitar Kelurahan Pertamanan, Kecamatan Panggungrejo, Kota Pasuruan, Provinsi Jawa Timur. Program kerja yang dilaksanakan adalah melaksanakan sosialisasi, pengerukan sedimen di saluran sekunder, mengecat saluran agar tampak cantik, memasang banner dan vertical garden, normalisasi saluran, mensosialisasikan pengetahuan tentang konsep teknologi penyedot sedimen (domen) untuk saluran yang tidak dapat dijangkau oleh tenaga manusia.

Harapan mahasiswa agar kegiatan normalisasi dan pembersihan saluran dapat dilakukan secara berkelanjutan, warga secara swadaya mampu menjaga saluran supaya tetap bersih dan sehat. Dan menjadi kebiasaan dan serta gaya hidup warga masyarakat dan lingkungan sekitar, sehingga masyarakat tersebut akan terbiasa dengan teknologi dengan saluran drainase yang berwawasan lingkungan (ecodrainage).

\section{UCAPAN TERIMA KASIH}

Ucapan terima kasih disampaikan kepada kepala Desa Kelurahan Pertamanan beserta Perangkat Desa telah menerima dan membantu mahasiswa peserta KKN-PPM selama 1 bulan dan menjalankan program kerja. Ucapan terima kasih juga disampaikan kepada Panitia KKN-PPM dan Ketua LPPM Universitas Islam Malang yang telah memberikan kesempatan dan memudahkan terlaksananya kegiatan KKN-PPM.

\section{DAFTAR RUJUKAN}

Arieza, U. (2018). Indonesia Penduduk Terbanyak Nomor 4 di Dunia, Siapa Juaranya? Okefinance.

https://economy.okezone.com/read/2018/07/21/320/1925559/indonesia-

penduduk-terbanyak-nomor-4-di-dunia-siapa-juaranya

Fairizi, D. (2015). Analisis dan Evaluasi Saluran Drainase pada Kawasan Perumnas Talang Kelapa di Sub DAS Lambidaro Kota Palembang. Jurnal Teknik Sipil Dan Lingkungan, 3(1), 755-765. https://ejournal.unsri.ac.id/index.php/jtsl/article/view/520

Oktiawan, W., \& Amalia, S. (2012). Pengaruh Kondisi Sistem Drainase, Persampahan dan Air Limbah Terhadap Kualitas Lingkungan (Studi kasus Kelurahan Kuningan Kecamatan Semarang Utara). Jurnal Presipitasi : Media Komunikasi Dan Pengembangan Teknik Lingkungan, 9(1), 41-50. https://doi.org/10.14710/presipitasi.v9i1.41-50

Rudyansyah. (2019). Peran United Nation Childrens Fun (UNICEF) Dalam Mengatasi Masalah Sanitasi di Papua. EJournal Ilmu Hubungan Internasional, 7(4), 1551-1562. https://ejournal.hi.fisip-unmul.ac.id/site/?p=3083

Sinatrya, A. K., \& Muniroh, L. (2019). Hubungan Faktor Water, Sanitation, and Hygiene (WASH) dengan Stunting di Wilayah Kerja Puskesmas Kotakulon, Kabupaten Bondowoso. Amerta Nutrition, 3(3), 164-170. https://doi.org/10.2473/amnt.v3i3.2019.164-170

Yunik'ati, Imam, R. M., Hariyadi, F., \& Choirotin, I. (2019). Sadar Pilah Sampah Dengan Konsep 4R (Reduce, Reuse, Recycle, Replace) Di Desa Gedongarum, Kanor, Bojonegoro. Jurnal Inovasi Hasil Pengabdian Masyarakat (JIPEMAS), 2(2), 81-87. https://doi.org/10.33474/jipemas.v2i2.1122 